\title{
Nutritional comparison between dried and ensiled indigofera, papaya and moringa leaves
}

\author{
A. Jayanegara*, V. Ardani and H. A. Sukria \\ Department of Nutrition and Feed Technology, Faculty of Animal Science, \\ Bogor Agricultural University, Jl. Agatis, Dramaga Campus, Bogor 16680 - Indonesia \\ *Corresponding E-mail: anuraga.jayanegara@gmail.com
}

Received June 10, 2018; Accepted December 08, 2018

\begin{abstract}
ABSTRAK
Penelitian ini bertujuan untuk mengevaluasi komposisi kimia, fermentasi dan kecernaan in vitro dari hijauan indigofera, pepaya dan kelor yang diberi perlakuan pengeringan dan ensilase. Perlakuan pengeringan pada hijauan dilakukan pada oven bersuhu $60^{\circ} \mathrm{C}$ selama 24 jam sedangkan perlakuan ensilase dilakukan selama 30 hari pada suhu ruang. Hijauan yang telah dikeringkan dan diensilase dianalisis komposisi kimianya, karakteristik fermentasi dan kecernaan secara in vitro. Perlakuan yang diujikan mengikuti pola faktorial $3 \times 2$ dengan faktor pertama adalah jenis hijauan (indigofera, pepaya dan kelor) dan faktor kedua adalah metode pengolahan (pengeringan dan silase). Analisis komposisi kimia dilakukan secara duplikat sedangkan evaluasi in vitro dilakukan dalam tiga ulangan. Hasil menunjukkan bahwa perlakuan ensilase menurunkan kandungan PK indigofera dan kelor namun tidak untuk pepaya. Ensilase juga menurunkan kandungan NDF dan NDICP dari semua hijauan dibandingkan dengan perlakuan pengeringan. Nilai $\mathrm{pH}$ dari semua silase tinggi dan mengandung konsentrasi amonia yang tinggi. Silase indigofera cenderung memiliki KCBK dan KCBO yang lebih rendah dibandingkan dengan indigofera yang dikeringkan $(\mathrm{P}<0.1)$. Dapat disimpulkan bahwa ensilase dari hijauan berprotein tinggi menyebabkan tingkat proteolisis yang juga tinggi.
\end{abstract}

Kata kunci: pengeringan, ensilase, fermentasi, proteolisis, rumen

\section{ABSTRACT}

The objective of this experiment was to evaluate chemical composition, in vitro fermentation and digestibility of dried and ensiled indigofera, papaya and moringa leaves. The leaves were subjected to artificial drying in an oven at $60^{\circ} \mathrm{C}$ for $24 \mathrm{~h}$ and ensiling treatment for $30 \mathrm{~d}$ under room temperature. Dried and ensiled samples were determined for chemical composition, silage fermentation characteristics and in vitro rumen fermentation and digestibility. The experimental design was a factorial design $3 \times 2$ in which the first factor was different leaves (indigofera, papaya and moringa) and the second factor was conservation treatments (drying and ensiling). Determination of chemical composition was performed in duplicate whereas in vitro evaluation was conducted in three replicates. Results showed that ensiling treatment decreased $\mathrm{CP}$ contents of indigofera and moringa but not papaya leaves. Ensiling also decreased NDF and NDICP contents of all experimental leaves in comparison to drying treatment. The $\mathrm{pH}$ of all silages was high and they were characterized with high ammonia concentrations. Ensiled indigofera tended to have lower IVDMD and IVOMD as compared to dried indigofera $(\mathrm{P}<0.1)$. It can be concluded that ensiling of high protein forages leads to considerable extent of proteolysis.

Keywords: drying, ensiling, fermentation, proteolysis, rumen 


\section{INTRODUCTION}

Protein supplementation into animal diet is essential in order to achieve optimal animal production and health. Although commercial concentrate may be used as a protein supplement, however, it may not be affordable to purchase especially for small-holder farmers. Farmers may therefore use high protein forages as protein supplements for their livestock. Indigofera (Indigofera zollingeriana), papaya (Carica papaya) and moringa (Moringa oleifera) leaves have been used as protein supplements in the diets of ruminant livestock due to their high protein contents (Jayanegara et al., 2010; Retnani et al., 2014; Suharlina et al., 2016a; 2016b). Several animal feeding trials using indigofera, papaya and moringa leaves confirmed their potencies as protein supplements. For instance, supplementation of $12 \%$ indigofera in the form of wafer increased average daily gain and feed efficiency of post-weaning Ettawa Grade goats by 55 and $35 \%$, respectively (Dianingtyas et al., 2017). Babiker et al. (2017) reported that feeding of moringa leaves to replace alfalfa resulted in a higher milk yield, better composition and quality of ewe and goat milk, and increased growth performance of kids and lambs.

Despite such promising nutrient profiles and application of the leaves for animal feeding, the effects of feed conservation on their nutritive values are subjected to further studies. Livestock sometimes do not consume fresh forages particularly during seasons when their availability are limited (Laconi and Jayanegara, 2015), and therefore need to consume conserved forages. In tropical regions, season with such limited fresh forage availability is typically during dry season (Zahera et al., 2015) whereas in temperate regions is during winter season (Yang et al., 2017). Common forage conservation practices are based on drying and ensiling methods. Drying may be performed naturally by means of sun drying or artificially by using a high temperature oven, commonly around $50-60^{\circ} \mathrm{C}$. Ensiling is performed in a silo under anaerobic condition and often with the aid of certain additives in order to result a high quality silage (König et al., 2017; Muck et al., 2018). The objective of the current experiment was therefore to evaluate and to compare chemical composition, in vitro fermentation and digestibility of dried and ensiled indigofera, papaya and moringa leaves.

\section{MATERIALS AND METHODS}

\section{Drying and ensiling of experimental materials}

Indigofera, papaya and moringa leaves were freshly collected from the experimental station of Bogor Agricultural University, Dramaga, Bogor. Each leaf species was divided into two portions; the first portion was subjected to artificial drying in an oven at $60^{\circ} \mathrm{C}$ for $24 \mathrm{~h}$ whereas the second portion was subjected to ensiling treatment. For the ensiling treatment, an amount of $1 \mathrm{~kg}$ of each leaf species was manually cut into ca $3 \mathrm{~mm}$ length. Each leaf species was inserted into a labscale silo (in three replicates), i.e. a high-density polyethylene bottle with 11 capacity, equipped with a rubber cap and slit. The slit enables gas from inside to release but prevents gas from outside to enter the silo. Ensiling was performed at room temperature $\left(\mathrm{ca} 27^{\circ} \mathrm{C}\right.$ ) for $30 \mathrm{~d}$. No starter or lactic acid bacteria from an external source was added in the present experiment. Weight of the bottles were measured before and after ensiling in order to determine weight loss of each leaf species. Ensiled samples were divided into two parts. The first part was mixed with distilled water $(1: 7 \mathrm{w} / \mathrm{v})$ and extracted in a blender. Supernatant was taken and subjected to silage quality determination, i.e. $\mathrm{pH}$, ammonia and total volatile fatty acid (VFA). The second part was oven-dried at $60^{\circ} \mathrm{C}$ for $24 \mathrm{~h}$, ground by a hammer mill $(1 \mathrm{~mm}$ screen size) and, together with leaf samples received drying treatment, were subjected to chemical composition analysis.

\section{Chemical Composition Analysis}

Dried and ensiled samples of indigofera, papaya and moringa leaves were determined for their crude protein $(\mathrm{CP})$, neutral detergent fiber (NDF), acid detergent fiber (ADF), neutral detergent insoluble crude protein (NDICP) and acid detergent insoluble crude protein (ADICP) contents. Analysis of $\mathrm{CP}$ was performed according to AOAC (2005) whereas NDF and ADF contents were analysed by following the procedure of Van Soest et al. (1991). Determination of NDICP and ADICP was conducted based on Licitra et al. (1996) as described in Jayanegara et al. (2016).

\section{In vitro Evaluation}

In vitro evaluation of dried and ensiled indigofera, papaya and moringa leaves was performed by gas production technique according to Theodorou et al. (1994). Approximately 750 
mg of each sample was incubated in a bottle together with $25 \mathrm{ml}$ rumen fluid and $50 \mathrm{ml}$ McDougall buffer under anaerobic condition. Rumen fluid was taken from two fistulated Ongole crossbred cattle before morning feeding. All bottles were incubated in a waterbath maintained at $39^{\circ} \mathrm{C}$ for $48 \mathrm{~h}$. Gas production was vented and recorded at regular time point intervals, i.e. $2,4,6,8,10,12,24,36$ and $48 \mathrm{~h}$ after the start of incubation by using a plastic syringe equipped with a needle. The purpose of measuring gas production at different time point intervals was to analyze the fermentation rate of various experimental treatments particularly during early incubation hours; higher gas production during early incubation indicates faster in vitro rumen fermentation rate and vice versa.Supernatant was taken for $\mathrm{pH}$, ammonia and total VFA determinations by employing a $\mathrm{pH}$ meter, Conway micro-diffusion technique and steam distillation method, respectively. Feed residual from rumen fluid incubation was subjected to another $48 \mathrm{~h}$ incubation with $75 \mathrm{ml}$ pepsin- $\mathrm{HCl} 0.2 \mathrm{~N}$ in order to determine in vitro dry matter digestibility (IVDMD) and in vitro organic matter digestibility (IVOMD).

\section{Statistical Analysis}

Analysis of variance (ANOVA) was applied to the data obtained by following a factorial randomized complete block design with three replicates. The first factor was forage source, i.e. indigofera, papaya and moringa leaves, whereas the second factor was forage treatment, i.e. drying and ensiling. The block or replicate was different incubation runs that performed in different weeks. For the in vitro gas production data at various time point intervals, anova was performed separately at each time point of gas production measurement A Duncan multiple range test was applied to significant anova results $(\mathrm{P}<0.05)$ in order to separate among different treatment means.

\section{RESULTS AND DISCUSSION}

\section{Chemical Composition and Silage Quality}

Indigofera, papaya and moringa leaves, both in dried and ensiled forms contained high CP, i.e. higher than 20\% DM (Table 1). Such high CP contents of indigofera, papaya and moringa leaves were also reported in other experiments, typically ranged from 24-28\% DM (Jayanegara et al., 2016; Kumalasari et al., 2017; Syarifuddin et al.,
2017). Ensiling treatment decreased CP contents of indigofera and moringa but not papaya leaves. Lower CP contents of these leaves after ensiling may be attributed to protein degradation into various amino acids and subsequent deamination of the amino acids to result ammonia and $\alpha$-keto acid (Lynch et al., 2014). Such protein degradation is possible due to the action of protease from microbial and plant origins. After ammonia is formed, the substance may be solubilized and therefore could not be recovered as $\mathrm{N}$ in the dry matter, resulting the $\mathrm{N}$ loss. In the case of papaya silage, apparently papain present in the forage (Manosroi et al., 2014) inhibits, to a certain extent, the action of microbial and plant protease and therefore does not reduce its $\mathrm{CP}$ content.

Indigofera contained higher NDF and ADF than those of papaya and moringa. The NDF and ADF contents of indigofera ranged around 27-31 and 25-28\% DM, respectively (Kumalasari et al., 2017), and the values obtained in this experiment were closely similar. Such higher NDF and ADF contents of indigofera as compared to those of moringa were confirmed by Jayanegara et al. (2010); the authors reported that moringa leaves contained 21.9 and $11.4 \%$ of $\mathrm{NDF}$ and ADF, respectively. Ensiling treatment decreased NDF and NDICP contents of all experimental leaves in comparison to drying treatment, but it was not the case for ADF. This indicates that lactic acid bacteria present in the silages may possess hemicellulolytic activity but not cellulolytic activity. Similar pattern was observed in the study of Jia et al. (2011). The authors reported that ensiling of bamboo shoot shell with lactic acid bacteria reduced its NDF content from 70.8 to $66.3 \%$ DM, but the ADF content did not decrease. Enzymatic activity of lactic acid bacteria may partially hydrolysed soluble cell wall components like hemicellulose (Adetunji et al., 2016) but it is less likely for the insoluble cell wall components.

Weight losses of indigofera, papaya and moringa silages after $30 \mathrm{~d}$ were generally low, around $2 \%$ or lower (Table 2 ). However, $\mathrm{pH}$ of all silages was high, being highest in papaya silage and lowest in moringa silage. The silages were characterized with high ammonia concentrations (no difference among the silages). Total VFA concentrations between indigofera, papaya and moringa silages were similar. High ammonia concentrations present in indigofera, papaya and moringa silages are the results of massive protein degradation and deamination as previously 
Table 1. Chemical Composition of Dried and Ensiled Indigofera, Papaya and Moringa Leaves (\% Dry Matter)

\begin{tabular}{rlllccc}
\hline \multicolumn{1}{c}{ Forage } & Treatment & CP & NDF & ADF & NDICP & ADICP \\
\hline Indigofera & Dried & 35.6 & 33.3 & 25.8 & 3.55 & 2.49 \\
& Ensiled & 26.2 & 27.6 & 26.2 & 2.56 & 2.23 \\
Papaya & Dried & 29.9 & 27.0 & 22.5 & 5.22 & 1.89 \\
& Ensiled & 29.9 & 24.8 & 22.2 & 1.62 & 0.35 \\
\multirow{3}{*}{ Moringa } & Dried & 28.7 & 26.8 & 16.6 & 5.44 & 1.66 \\
& Ensiled & 24.9 & 21.9 & 18.2 & 1.82 & 1.45 \\
\hline
\end{tabular}

CP: crude protein; NDF: neutral detergent fiber; ADF: acid detergent fiber; NDICP: neutral detergent insoluble crude protein; ADICP: acid detergent insoluble crude protein

Table 2. Fermentation Characteristics of Indigofera, Papaya and Moringa Leaf Silages

\begin{tabular}{lcccc}
\hline \multicolumn{1}{c}{ Forage } & Weight loss $(\%)$ & $\mathrm{pH}$ & $\mathrm{NH}_{3}(\mathrm{mM})$ & VFA $(\mathrm{mM})$ \\
\hline Indigofera silage & $1.74^{\mathrm{ab}}$ & $5.23^{\mathrm{a}}$ & 83.2 & 182 \\
Papaya silage & $1.00^{\mathrm{a}}$ & $5.70^{\mathrm{b}}$ & 82.7 & 167 \\
Moringa silage & $2.04^{\mathrm{b}}$ & $4.87^{\mathrm{a}}$ & 94.3 & 144 \\
SEM & 0.193 & 0.134 & 4.73 & 10.1 \\
P-value & 0.045 & 0.007 & 0.593 & 0.378 \\
\hline
\end{tabular}

Different superscripts within the same column are significantly different at $\mathrm{P}<0.05$. VFA: volatile fatty acid; SEM: standard error of mean

discussed above. Since ammonia is rather alkali, its high concentration causes the high $\mathrm{pH}$ condition in the silages. Such high $\mathrm{pH}$ may induce the growth of undesirable bacteria such as Clostridia sp. and in turn decreases silage quality (Zheng et al., 2017). Future research is therefore needed to decelerate proteolysis in high protein silage by adding a certain additive such as tannin since the plant secondary compound forms complex with protein (Jayanegara and Palupi, 2010) and potentially protect protein from degradation.

\section{In vitro Rumen Fermentation and Digestibility}

Dried indigofera and moringa leaves had higher gas production than that of dried papaya leaves $(\mathrm{P}<0.05)$ particularly during early incubation hours (Table 3). Ensiling decreased gas production of indigofera and moringa leaves $(\mathrm{P}<0.05)$ but not for papaya leaves. Cumulative gas production increased with increasing incubation period but with decreasing rate. Higher gas production of dried moringa as compared to dried papaya was expected due to the lower ADF content of moringa despite relatively similar NDF content. Gas production is primarily as a result of carbohydrate fermentation in the rumen (Getachew et al., 1998), including hemicellulose that can be estimated as the difference between NDF and ADF values. However, this was not the case for indigofera in which it contained higher ADF than that of papaya but had gas production as well. It might be that other factors influencing gas production were present such as different types of carbohydrate, degradability and fermentability of carbohydrate under ruminal environment (Morenz et al., 2012) and antinutritive compounds (Laconi and Widiyastuti, 2010; Kondo et al., 2014), in which these parameters were not measured in the present 
Table 3. Effects of Drying and Ensiling on in vitro Gas Production (ml) of Indigofera, Papaya and Moringa Leaves

\begin{tabular}{|c|c|c|c|c|c|c|c|c|c|c|}
\hline \multirow{2}{*}{ Forage } & \multirow{2}{*}{ Treatment } & \multicolumn{9}{|c|}{ Incubation period (h) } \\
\hline & & 2 & 4 & 6 & 8 & 10 & 12 & 24 & 36 & 48 \\
\hline \multirow[t]{2}{*}{ Indigofera } & Dried & $21^{b}$ & $33^{b}$ & $46^{\mathrm{b}}$ & 49 & $68^{\mathrm{a}}$ & $79^{\mathrm{a}}$ & 101 & $119^{\mathrm{bc}}$ & $128^{\mathrm{bc}}$ \\
\hline & Ensiled & $11^{\mathrm{a}}$ & $23^{\mathrm{a}}$ & $36^{\mathrm{a}}$ & 50 & $62^{\mathrm{a}}$ & $73^{\mathrm{a}}$ & 92 & $107^{\mathrm{a}}$ & $114^{\mathrm{a}}$ \\
\hline \multirow[t]{2}{*}{ Papaya } & Dried & $10^{\mathrm{a}}$ & $24^{\mathrm{a}}$ & $38^{\mathrm{a}}$ & 52 & $68^{\mathrm{a}}$ & $80^{\mathrm{a}}$ & 93 & $109^{\mathrm{ab}}$ & $117^{\mathrm{a}}$ \\
\hline & Ensiled & $10^{\mathrm{a}}$ & $21^{\mathrm{a}}$ & $35^{\mathrm{a}}$ & 47 & $66^{\mathrm{a}}$ & $80^{\mathrm{a}}$ & 100 & $114^{\mathrm{abc}}$ & $124^{\mathrm{abc}}$ \\
\hline \multirow[t]{2}{*}{ Moringa } & Dried & $20^{\mathrm{b}}$ & $35^{\mathrm{b}}$ & $51^{b}$ & 65 & $78^{\mathrm{b}}$ & $88^{\mathrm{b}}$ & 103 & $121^{\mathrm{c}}$ & $130^{\mathrm{c}}$ \\
\hline & Ensiled & $13^{\mathrm{a}}$ & $24^{\mathrm{a}}$ & $38^{\mathrm{a}}$ & 54 & $68^{\mathrm{a}}$ & $79^{\mathrm{a}}$ & 97 & $110^{\mathrm{ab}}$ & $119^{\mathrm{ab}}$ \\
\hline SEM & & 1.34 & 1.69 & 1.93 & 2.44 & 2.62 & 2.78 & 1.70 & 1.68 & 1.81 \\
\hline \multicolumn{11}{|l|}{ P-value } \\
\hline \multicolumn{2}{|l|}{ Forage } & 0.017 & 0.013 & 0.004 & 0.054 & 0.004 & 0.025 & 0.516 & 0.451 & 0.438 \\
\hline \multicolumn{2}{|l|}{ Treatment } & 0.006 & 0.001 & $<0.001$ & 0.154 & 0.004 & 0.031 & 0.384 & 0.033 & 0.044 \\
\hline \multicolumn{2}{|c|}{ Forage $\times$ Treatment } & 0.099 & 0.126 & 0.093 & 0.338 & 0.168 & 0.209 & 0.119 & 0.031 & 0.015 \\
\hline
\end{tabular}

Different superscripts within the same column are significantly different at $\mathrm{P}<0.05 ; \quad$ SEM: standard error of mean.

experiment. Lower gas production after ensiling treatment apparently related to partial utilization of water soluble carbohydrate by lactic acid bacteria and other microorganims present in silage, thus contributing to a reduced gas production.

Ruminal $\mathrm{pH}$, total VFA and ammonia concentrations of dried and ensiled indigofera, papaya and moringa leaves were indifferent (Table 4). The values of these parameters are within the normal range. Ensiled indigofera tended to have lower IVDMD and IVOMD as compared to dried indigofera $(\mathrm{P}<0.1)$. For papaya and moringa leaves, drying and ensiling treatments had similar IVDMD and IVOMD values. The IVDMD and IVOMD values for the dried leaves were closely similar to literatures. For instance, Abdullah (2010) reported that IVDMD and IVOMD of indigofera were 67.585.5 and $60.3-82.7 \%$, respectively. Dried papaya leaves had IVDMD and IVOMD values of 74.9 and $70.9 \%$, respectively (Jayanegara et al., 2016). With regard to moringa, Paengkoum et al. (2013) reported that total tract DM digestibility of moringa leaves was $70.4 \%$, in which rumen degradability and intestinal digestibility of the leaves contributed 52.9 and $17.5 \%$, respectively.
Further, Kleden et al. (2017) reported that IVDMD of four moringa varieties from East Flores Regency ranged between 63.3 and $67.1 \%$. Indication of lower in vitro digestibility observed in indigofera silage is apparently as a result of lactic acid bacteria consumption on soluble carbohydrate.

\section{CONCLUSION}

Indigofera, papaya and moringa leaves are potential forages for use as protein supplements for ruminants, either in dried or ensiled form. Ensiling of these high protein forages however leads to considerable extent of proteolysis as indicated by lower $\mathrm{CP}$ contents, high $\mathrm{pH}$ and high ammonia concentrations in the silage materials. Future research is required in order to prevent or at least to decelerate the proteolysis by using certain silage additives.

\section{ACKNOWLEDGEMENT}

This research was funded by Kementerian Riset, Teknologi dan Pendidikan Tinggi (KEMENRISTEKDIKTI) through "Penelitian Berbasis Kompetensi" research grant, contract 
Table 4. Effects of Drying and Ensiling on in vitro Rumen Fermentation and Digestibility of Indigofera, Papaya and Moringa Leaves

\begin{tabular}{llllllc}
\hline \multicolumn{1}{c}{ Forage } & Treatment & $\mathrm{pH}$ & $\begin{array}{c}\text { VFA } \\
(\mathrm{mM})\end{array}$ & $\begin{array}{c}\mathrm{NH}_{3} \\
(\mathrm{mM})\end{array}$ & $\begin{array}{c}\text { IVDMD } \\
(\%)\end{array}$ & $\begin{array}{c}\text { IVOMD } \\
(\%)\end{array}$ \\
\hline Indigofera & Dried & 6.62 & 168 & 16.3 & $70.1^{\mathrm{ab}}$ & 69.5 \\
& Ensiled & 6.60 & 140 & 15.3 & $66.0^{\mathrm{a}}$ & 64.8 \\
Papaya & Dried & 6.67 & 151 & 17.5 & $73.4^{\mathrm{b}}$ & 70.9 \\
& Ensiled & 6.64 & 174 & 18.7 & $73.7^{\mathrm{b}}$ & 71.2 \\
Moringa & Dried & 6.68 & 124 & 11.2 & $73.1^{\mathrm{b}}$ & 71.3 \\
& Ensiled & 6.61 & 195 & 19.2 & $70.7^{\mathrm{b}}$ & 68.4 \\
SEM & & 0.034 & 10.2 & 1.31 & 1.59 & 1.50 \\
P-value & & & & & & \\
Forage & & 0.580 & 0.876 & 0.474 & 0.006 & 0.055 \\
Treatment & & 0.261 & 0.151 & 0.361 & 0.088 & 0.061 \\
Forage×Treatment & 0.798 & 0.054 & 0.253 & 0.293 & 0.240 \\
\hline
\end{tabular}

Different superscripts within the same column are significantly different at $\mathrm{P}<0.05$; VFA: volatile fatty acid; IVDMD: in vitro dry matter digestibility; IVOMD: in vitro organic matter digestibility; SEM: standard error of mean.

number 129/SP2H/PTNBH/DRPM/2018, year 2018.

\section{REFERENCES}

Abdullah, L. 2010. Herbage production and quality of shrub indigofera treated by different concentration of foliar fertilizer. Med. Pet. 33:169-175.

Adetunji, A.I., H. du Clou, S.N. Walford and J.R.N. Taylor. 2016. Complementary effects of cell wall degrading enzymes together with lactic acid fermentation on cassava tuber cell wall breakdown. Ind. Crops Prod. 90:110-117.

Babiker, E.E., F.A.L. Juhaimi, K. Ghafoor and K.A. Abdoun. 2017. Comparative study on feeding value of Moringa leaves as a partial replacement for alfalfa hay in ewes and goats. Livest. Sci. 195:21-26.

Dianingtyas, B.D., Y. Retnani and D. Evvyernie. 2017. Legume wafer supplementation to increase the performance of post-weaning Ettawa Grade goats. Med. Pet. 40:42-46.

Getachew, G., M. Blummel, H.P.S. Makkar and K. Becker. 1998. In vitro gas measuring techniques for assessment of nutritional quality of feeds: a review. Anim. Feed Sci. Technol. 72:261-281.
Jayanegara, A., and E. Palupi. 2010. Condensed tannin effects on nitrogen digestion in ruminants: A meta-analysis from in vitro and in vivo studies. Med. Pet. 33:176-181.

Jayanegara, A., T. Sabhan, A.K. Takyi, A.O. Salih and E.M. Hoffmann. 2010. Ruminal fermentation kinetics of Moringa and Peltiphyllum supplements during early incubation period in the in vitro Reading Pressure Technique. J. Indonesian Trop. Anim. Agric. 35:165-171.

Jayanegara, A., S.P. Dewi, N. Laylli, E.B. Laconi, Nahrowi and M. Ridla. 2016. Determination of cell wall protein from selected feedstuffs and its relationship with ruminal protein digestibility in vitro. Med. Pet. 39:134-140.

Jia, Y.F., W.Y. Shi, L.H. Wu and H.L. Wang. 2011. Effects of ensilage on the preservation of bamboo shoot shells and their fibre characteristics. J. Trop. Forest Sci. 23:396403.

Kleden, M.M., H. Soetanto, K. Kusmartono and K. Kuswanto. 2017. Genetic diversity evaluation of Moringa oleifera, lam from east flores regency using marker random amplified polymorphic DNA (RAPD) and its relationship to chemical composition and in vitro gas production. Agrivita 39:219-231. 
Kondo, M., Y. Hirano, N. Ikai, K. Kita, A. Jayanegara and H.-O. Yokota. 2014. Assessment of anti-nutritive activity of tannins in tea by-products based on in vitro rumen fermentation. Asian-Australas. J. Anim. Sci. 27:1571-1576.

König, W., M. Lamminen, K. Weiss, T.T. Tuomivirta, S. Sanz Muñoz, H. Fritze, K. Elo, L. Puhakka, A. Vanhatalo and S. Jaakkola. 2017. The effect of additives on the quality of white lupin-wheat silage assessed by fermentation pattern and qPCR quantification of clostridia. Grass Forage Sci. 72:757-771.

Kumalasari, N.R., G.P. Wicaksono and L. Abdullah. 2017. Plant growth pattern, forage yield, and quality of Indigofera zollingeriana influenced by row spacing. Med. Pet. 40:1419.

Laconi, E.B., and T. Widiyastuti. 2010. Lamtoro leaf (Leucaena leucocephala) xanthophylls content as the result of physical and chemical detoxification of mimosine. Med. Pet. 33:5054.

Laconi, E.B., and A. Jayanegara. 2015. Improving nutritional quality of cocoa pod (Theobroma cacao) through chemical and biological treatments for ruminant feeding: in vitro and in vivo evaluation. Asian-Australas. J. Anim. Sci. 28:343-350.

Lynch, J.P., L. Jin, E.C. Lara, J. Baah and K.A. Beauchemin. 2014. The effect of exogenous fibrolytic enzymes and a ferulic acid esteraseproducing inoculant on the fibre degradability, chemical composition and conservation characteristics of alfalfa silage. Anim. Feed Sci. Technol. 193:21-31.

Manosroi, A., C. Chankhampan, K. Pattamapun, W. Manosroi and J. Manosroi. 2014. Antioxidant and gelatinolytic activities of papain from papaya latex and bromelain from pineapple fruits. Chiang Mai J. Sci. 41:635648.

Morenz, M.J.F., J.F.C. da Silva, L.J.M. Aroeira, F. Deresz, H.M. Vásquez, F.C.F. Lopes, D.S.C. Paciullo and L.O. Tedeschi. 2012. Evaluation of the Cornell Net Carbohydrate and Protein System model on the prediction of dry matter intake and milk production of grazing crossbred cows. Rev. Bras. Zootec. 41:398406.

Muck, R.E., E.M.G. Nadeau, T.A. McAllister, F.E. Contreras-Govea, M.C. Santos and L. Kung Jr. 2018. Silage review: Recent advances and future uses of silage additives. J. Dairy Sci. 101:3980-4000.

Paengkoum, P., S. Traiyakun and S. Paengkoum. 2013. Intestinal digestibility of enrichedprotein fodders measured by mobile bag incubated with or without pepsin- $\mathrm{HCl}$ and three-step techniques. South Afr. J. Anim. Sci. 43:511-518.

Retnani, Y., I.G. Permana and L.C. Purba. 2014. Physical characteristic and palatability of biscuit bio-supplement for dairy goat. Pak. J. Biol. Sci. 17:725-729.

Syarifuddin, N.A., A.L. Toleng, D.P. Rahardja, Ismartoyo and M. Yusuf. 2017. Improving libido and sperm quality of Bali bulls by supplementation of Moringa oleifera leaves. Med. Pet. 40:88-93.

Suharlina, D.A. Astuti, Nahrowi, A. Jayanegara and L. Abdullah. 2016a. In vitro evaluation of concentrate feed containing Indigofera zollingeriana in goat. J. Indonesian Trop. Anim. Agric. 41:196-203.

Suharlina, D.A. Astuti, Nahrowi, A. Jayanegara and L. Abdullah. 2016b. Nutritional evaluation of dairy goat rations containing Indigofera zollingeriana by using in vitro rumen fermentation technique (RUSITEC). Int. J. Dairy Sci. 11:100-105.

Theodorou, M.K., B.A. Williams, M.S. Dhanoa, A.B. McAllan and J. France. 1994. A simple gas production method using a pressure transducer to determine the fermentation kinetics of ruminant feeds. Anim. Feed Sci. Technol. 48:185-197.

Van Soest, P.J., J.B. Robertson and B.A. Lewis. 1991. Methods for dietary fiber, neutral detergent fiber, and nonstarch polysaccharides in relation to animal nutrition. J. Dairy Sci. 74:3583-3597.

Yang, Z., Y. Wang, X. Yuan, L. Wang and D. Wang. 2017. Forage intake and weight gain of ewes is affected by roughage mixes during winter in northeastern China. Anim. Sci. J. 88:1058-1065.

Zahera, R., I.G. Permana and Despal. 2015. Utilization of mungbean's green house fodder and silage in the ration for lactating dairy cows. Med. Pet. 38:123-131.

Zheng, M.L., D.Z. Niu, D. Jiang, S.S. Zuo and C.C. Xu. 2017. Dynamics of microbial community during ensiling direct-cut alfalfa with and without LAB inoculant and sugar. J. Appl. Microbiol. 122:1456-1470. 